Л.О. Петрова, О.Ю. Панфілов

Харківський національний університет Повітряних Сил ім. І. Кожедуба, Харків

\title{
ГЕНДЕРНА РІВНІСТЬ В АРМІї: УЧАСТЬ ЖІНОК У ВІЙСЬКОВИХ ДІЯХ В АНТИТЕРОРИСТИЧНІЙ ОПЕРАЦІЇ (ОПЕРАЦІЇ ОБ'ЄДНАНИХ СИЛ)
}

Стаття присвячена аналізу актуальних проблем тендерної політики в армії. Обтрунтовано принцип рівності, який має декілька проявів, одним із яких є принцип гендерної рівності, щуо означає рівний підхід до всього незалежно від статі. Проаналізовано гендерні стереотипи, гендерні нормативи поведінки і проблеми гендерної ідентифікачії у сучасному украӥнському суспільстві. Проблеми гендерних відмінностей особистісних властивостей пов'язані з тим, щзо внаслідок постійних динамічних змін у світі, виникає все більше запитань щчодо впливу певних гендерних стереотипів на професійну діяльність особистості. Доведено, що на сьогодні гендерна політика у Збройних Силах України не повністю відображає загальносвітові тенденції у сфері гендерних відносин. На підставі даних інтерв'ювання розглядаються ролі жінок в Антитерористичній операчії (операції Об’єднаних сил) на сході України і їх боротьба за рівні права і можливості в своїй державі.

Ключові слова: армія, гендер, гендерний стереотип, військовослужбовці-жінки, гендерна рівність.

\section{Вступ}

Постановка проблеми. Упродовж тривалого часу історичну картину світу створювали чоловіки, виражаючи свій погляд на навколишню дійсність, структуру ідеальної сім'ї, місце і роль жінки в соціальному просторі.

Щодо участі жінок у військовій діяльності тривалий час існувало багато суперечок. Противники гендерної рівності пояснювали це тим, що жінки не спроможні ані морально ані фізично проходити військову службу.

Сучасні збройні сили більшості країн світу вже немислимі без представниць прекрасної статі. Це об'єктивний процес фемінізації суспільства, що характеризується посиленням ролі і впливу жінки в армії. Для захисту прав жінки, дослідники провели чимало соціологічних досліджень, які довели, що жінки і чоловіки однаково страждають від психологічного та фізичного впливу та напруженого графіку роботи. Сьогодні вже ні в кого не викликає сумніву про необхідність залучення жінок на військову службу в якості повноправних суб'єктів військової діяльності.

Фемінізація армії $\epsilon$ специфічною частиною об'єктивного процесу фемінізації суспільства і виражається посиленням ролі і впливу жінки в армії, а також функціональною залежністю останніх від ступеня реалізації особистісного потенціалу військовослужбовцями-жінками.

Актуальність проблеми зумовлена збільшенням чисельності жінок-військовослужбовців в армії; розширенням кола військово-облікових спеціальностей і посад, які обіймають жінки-військовослуж- бовці; домінуванням застарілих стереотипів щодо місця та ролі жінок у Збройних Силах.

Додатково тему дослідження актуалізує необхідність поглиблення демократичних перетворень в Україні, з'ясування особливостей участі жінок у воєнних діях в зоні операції Об'єднаних сил (ООС)/Антитерористичної операції (АТО), виявивши як можливі успіхи, так і проблеми інтеграції жінок як військовослужбовців.

Аналіз останніх досліджень і публікацій. Особливості статево-рольової диференціації та гендерної соціалізації досліджувалися у працях Т. Голованової [1], М. Палагнюк [2], О. Рубан [3].

На думку О.А. Вороніної [4] фундаментальною підставою гендерної теорії $є$ уявлення про те, що майже всі традиційно вважають “природними” відмінності між статями, які мають під собою не біологічні, а соціальні підстави.

Основні теоретико-методологічні підходи до дослідження проблеми гендерної політики в Збройних Силах України, стан і тенденції іiі реалізації знайшли відображення в працях Н. Вавілової, Н. Дубчак, О. Дяченко, Н. Клименко, В. Кротикова, В. Малюги, О. Олійник, В. Топальського, Ю Калагіна та ін. [5-8].

Мета статті - на основі аналізу теорії і практики гендерної рівності у військовій сфері з'ясувати роль і місце жінки в бойових діях в АТО/ООС, визначити переваги та недоліки жінки як військовослужбовця.

\section{Виклад основного матеріалу}

Сучасні збройні сили більшості країн світу вже немислимі без представниць прекрасної статі. Сьо- 
годні у Збройних Силах України проходять службу та працюють понад 47 тисяч жінок, серед яких майже третина - це жінки-військовослужбовці і вже ні в кого не викликає сумніву про необхідність залучення жінок на військову службу в якості повноправних суб'єктів військової діяльності.

Збройні Сили $є$ інститутом, на який покладається надважлива функція держави - оборона України, захист іiі територіальної цілісності та суверенітету, коли має використовуватися весь потенціал людського фактора (як чоловіків, так і жінок). Разом 3 цим, для оптимальної інтеграції жінок у військові колективи необхідні адекватні гендерні стереотипи, що поширюються в армійському середовищі. Традиційні (патріархальні) стереотипи, котрі домінували в минулому і мають місце бути сьогодні, не сприяють, а навпаки ускладнюють інтеграцію жінок у збройні сили.

Відомо, що передумовою конструювання гендеру та гендерної поведінки є гендерні стереотипи уявлення про якості і норми поведінки чоловіків і жінок.

Розуміння гендерного стереотипу надзвичайно важливо, оскільки кожна людина, незалежно від його гендерної приналежності, $є$ індивідуальністю, зі своїм набором психологічних якостей і властивостей, співвідношенням маскулінності і фемінності у психіці, дозволить кожній індивідуальності і суспільству в цілому стати більш продуктивним, розвинутим і гармонійним в будь-якій сфері діяльності.

Гендерні стереотипи, як спрощені, стійкі, емоційно забарвлені образи поведінки й рис характеру чоловіків і жінок, проявляють себе в усіх сферах життя людини: у самосвідомості, в міжособистісному спілкуванні, в міжгруповій взаємодії.

Гендерні стереотипи можна об’єднати в три групи:

- стереотипи маскулінності/фемінності, що нав'язують людям певні думки про соматичні, психічні та поведінкові якості, характерні для чоловіків і жінок;

- стереотипи сімейних і професійних ролей, пов'язані з гендером;

- стереотипи, пов'язані зі змістом діяльності чоловіків і жінок. Гендерні стереотипи можуть змінюватися залежно від соціальних, економічних чи політичних змін, але цей процес відбувається досить повільно [9].

Фемінізація збройних сил актуалізувала дискусію про становище жінок в армії, і, відповідно, викликала наукову потребу в переоцінці колишніх уявлень про місце жінок і їх ролі.

Аналіз результатів дослідження гендерних стереотипів, поширених серед військовослужбовцівжінок, дозволив [8] виділити основну групу - гендерно-детерміновані стереотипів, які структурують військову діяльність на чоловічу і жіночу. Гендернодетерміновані стереотипні уявлення, в рамках яких професійні можливості військовослужбовців жіночої статті визнаються вище від можливостей чоловіків, у певних видах військово-професійної діяльності виявлено у 57\% військовослужбовців-жінок. В основі даних стереотипів лежить уявлення про те, що жінки-військовослужбовці більш конкурентоздатні в тих видах військово-професійної діяльності, де необхідні певні особистісні якості (увага, посидючість, витримка, пунктуальність, чутливість, креативне мислення і т.д.).

Автор даного дослідження наголошує, що до даних видів військово-професійної діяльності не належать бойова діяльність (управління операціями i бойовими діями, безпосередня участь в операціях і бойових діях, виконання диверсійних операцій в тилу ворога і т.д.), яка пов'язана з фізичними перевантаженнями. Автор дотримується позиції, що наявність військовослужбовців-жінок 3 гендернодетермінованими стереотипами в сучасних умовах сприяє більш ефективній організації військової служби. За умови однакової підготовки та однакового ставлення до жінок та чоловіків вони так само ефективно виконують свої обов'язки як і чоловіки. Тим більше, що не кожен чоловік це гарний воїн.

Враховуючи зміну характеру сучасних бойових дій, кількість м'язів не відіграє значущу роль, а отже гендер не повинен виступати основним чинником під час визначення ролей чоловіків і жінок у військових структурах.

За результатами соціологічного дослідження, яке було проведено в Харківському, Чугуївському та Дніпропетровському гарнізонах у січні - лютому 2015 року, метою якого було вивчення соціальнопрофесійного потенціалу особистості військовослужбовця-жінки, було з'ясовано, що військовослужбовці-жінки більш “відкриті” до потреб суспільства ніж чоловіки, а мотив приносити найбільшу користь суспільству посідає одну з перших позицій в їхній ієрархії соціальних цінностей. Яскравим свідченням “відкритості” мотивації військовослужбовця-жінки $€$ високий рейтинг мотиву “бути корисною суспільству в надзвичайних ситуаціях”. Адже саме цей мотив спроможний забезпечити ефективне виконання нових функцій армії, пов'язаних з її участю в подоланні наслідків екологічних і техногенних катастроф, проявами тероризму тощо.

Отримані дані щодо мотивації військовослужбовців-жінок показують, що в їі структурі професійна орієнтація гармонійно поєднується із соціальною орієнтацією.

Ще переконливішими на користь “фемінізації” Збройних Сил України стає структура якостей військового спеціаліста (офіцера), складена за відповідями військовослужбовців-жінок. Зокрема, високий 
рейтинг отримали особистісні якості, до яких належать: відповідальність за наслідки професійної діяльності (77,7\%), вміння ставити суспільні інтереси над особистими $(59,5 \%)$; недостатньо високий рейтинг отримали такі якості: сумлінність $(38,9 \%)$, ініціатива, винахідливість (37,8\%). Помітним є високий ступінь самооцінки професійно важливих якостей, тобто жінка-офіцер достатньо високо оцінює себе як офіцера-професіонала.

Результати дослідження щодо визначення професійних якостей військовослужбовця військовослужбовцями-чоловіками показали іншу картину. У цілому по всьому масиву опитаних військовослужбовців-чоловіків високий рейтинг отримали особистісні якості, до яких належать: готовність до ризику (62,5\%). організаторські здібності (52,4\%), самостійність, незалежність $(52 \%)$. Ці якості $\epsilon$ обов'язковими елементами в структурі особистості офіцера - офіцера армії тоталітарної держави, що, на жаль, не відповідає моделі армії демократичної держави, якою є сучасна Україна.

Науковці вважають, що присутність жінок значно пом'якшує морально-психологічну атмосферу у військових колективах, змушує командирів та начальників бути більш стриманими і головне - значно підвищується культура взаємостосунків між військовослужбовцями в самому колективі. Слід зазначити, що на відміну від чоловіків освітній рівень військовослужбовців-жінок значно вищий [10].

За результатами досліджень Н. Правдивець основними чинниками розвитку професійної ідентичності саме у жінок (військовослужбовців) $є$ такі, як диференціація професійних та гендерних ролей, адекватна та стійка самооцінка, альтруїстична спрямованість, орієнтація на працю та саморозвиток [11].

Які ж основні причини, що спонукають жінку до обрання військової служби? Результати дослідження показують, що більшість жінок йдуть на службу з економічних причин - приваблює задовільне грошеве утримання. Важливе значення має можливість самореалізації в армійських умовах. Поряд із цим військова служба надає можливість жінкам отримати спеціальність, освіту для подальшого цивільного життя після звільнення з армії.

Почуття соціальної захищеності, постійний заробіток, речове, медичне забезпечення, гарантована оплачувальна відпустка - все це сприяє залученню жінок до лав Збройних Сил.

Неабияку роль у прагненні жінок вступити на військову службу відіграє й такий фактор, як можливість влаштувати особисте життя, знайти друзів, продовжити родинні традиції.

Для країни надто важлива якість війська, тому Збройні Сили України на сьогоднішній день не зважають на стать, а в першу чергу важливою ознакою є професіоналізм. Міністерство оборони почало просуватися в цьому напрямі доволі активно і стало чи не єдиним відомством, яке повністю взяло на себе виконання цілей партнерства із НАТО саме в гендерних аспектах військової служби. Ще у 2016 році було розширено перелік військових професій для жінок. Якщо раніше вони претендували переважно на посади зв'язківців, діловодів, кухарів (не бойових), то на сьогоднішній день вони можуть бути механіками, водіями, артилеристами, тощо.

327 жовтня 2018 року набув чинності Закон “Про внесення змін до деяких законів України щодо забезпечення рівних прав та можливостей жінок і чоловіків під час проходження військової служби в Збройних Силах України та інших військових формуваннях”, який зрівняв права жінок та чоловіків. Віднині жінки виконують військовий обов'язок на рівних засадах із чоловіками, за винятком випадків, передбачених законодавством з питань охорони материнства та дитинства, а також заборони дискримінації за ознакою статі.

Тут варто зазначити, що до недавнього часу у світі були лише дві країни, в яких жінки були позбавлені будь-яких обмежень і проходили військову службу нарівні з чоловіками - це США і Австралія. Більше десяти років потому Міністерство оборони США відкрило всі штати для жінок.

В США у жовтні 2018 року жінка навіть очолила Командування сил армії США. В Австралії 3 2011 року вже немає жодних обмежень для жінок на будь-яких посадах, а в Норвегії аналогічний закон ухвалено ще 1985 року. Проте всі показники перебиває Ізраїль -34\% загальної чисельності ЦАХАЛ $є$ саме жінки. Військовослужбовці нині проходять службу і на посадах миротворчого персоналу в складі Місії ООН зі стабілізації в Конго (спостерігач), Мiciї ООН у Республіці Південний Судан (штабний офіцер) та Спільних миротворчих силах у зоні безпеки Придністровського регіону Республіки Молдова (спостерігач) [12].

У Збройних Силах України працюють над тим, аби кількість жінок-військовослужбовців зростала. Наразі триває активний відбір та підготовка жінок 3 подальшим направленням до складу міжнародних операцій з підтримки миру і безпеки на посади офіцерів штабу та радників з гендерних питань.

Головна новація цьогорічної вступної кампанії - дівчата-ліцеїстки. За підсумками первинної військово-професійної підготовки, яка традиційно відбулася в Міжнародному центрі миротворчості та безпеки, курсантки не поступалися юнакам, а за рівнем мотивації та жаги до здобуття знань часто навіть випереджали хлопців. Шанси в українських жінок на здобуття звання генерала досить великі. Кількість жінок-офіцерів, які навчаються на оперативному рівні, за останні п'ять років зросла в декілька разів. Якщо раніше жінка на оперативному рівні - це 
поодинокий випадок на кшталт медика чи гуманітарія, то нині жінки є і на командних спеціальностях. За кілька років можливо опинимось у ситуації, коли жінки претендуватимуть на заміщення керівних посад не лише в галузі юриспруденції чи медзабезпечення, а й на серйозних командних посадах, як у НАТО.

Отримані результати дослідження надають можливість зауважити, що головне - це готовність офіцерів-чоловіків до сприйняття і виконання рішень та команд, які віддає жінка-офіцер. Під час нинішньої війни всі побачили, що і в нас $є$ військовослужбовиці, які дивують навіть західних партнерів, але жінка-військовослужбовець за посадою має виконувати увесь обсяг навантаження на рівні з чоловіками згідно з їі посадовими обов'язками. Війна міцно закріплена у суспільній свідомості як традиційно “чоловіча" справа. Жінки розглядаються як жертви війни, часто як об'єкти, в той час як чоловіки є суб'єктами та іiі агентами.

Стереотипи представляють нам чоловіка зі зброєю в руках та жінку, яка, у кращому разі, виконує на фронті обслуговуючу щодо військовика роль, наприклад, медичної працівниці, а у гіршому - чекає на чоловіка вдома, доки він іiї захищає. Зазначається, що роль жінок у військових конфліктах може бути миротворчою, а позиція - пацифістською [13].

Деякі феміністки стверджують, що залучення жінок до військової служби є важливою частиною рівних прав i, зрештою, призводить до набуття останніми повноцінного громадянства у своїх країнах. Це загалом поширена позиція так званого ліберального фемінізму.

Інші дослідниці вважають, що мілітаризм навряд чи може принести більше фемінізму та рівності до суспільства загалом, натомість обстоюючи принципово пацифістські та антимілітаристські погляди. Зокрема, армія із позиції радикального фемінізму повинна перестати бути армією, так і військові повинні відмовитися від статусу інструментів і керівників насилля.

У 2014 році на службу до ЗСУ у зв'язку з частковою мобілізацією було призвано близько 100 військовозобов'язаних жінок. Жінок, що хотіли би воювати, насправді значно більше, тому вони йшли та йдуть воювати добровільно.

3 моменту початку антитерористичної операції на Донбасі статус учасника бойових дій отримали 9916 жінок, а 166 удостоїлися державних нагород. Більше того, Україна вже має перших жінок генералів: Людмилу Шугалей та Оксану Хоменко. Розвиток України в сфері гендерної політики в майбутньому неодмінно досягне високого показника.

Спостерігається тенденція, що відмінності у ставленні до гендерних ролей в армії пов'язані, зокрема, з професією жінки на війні: жінки-солдати частіше говорять про рівність між чоловіками і жінками на війні і добиваються поваги й ставлення до себе як до побратима.

Медсестри і психологи демонструють більш традиційне ставлення до розподілу гендерних ролей і приймають турботу солдатів. Проте це лише спостереження щодо образів жінок в ООС (АТO), показаних у засобах масової інформації. На основі даного матеріалу можна виділити три основні образи жінки в АТО/ООС, які зображені в засобах масової інформації: жінка-воїн; турботлива помічниця; революціонерка.

Жінка-воїн - це образ жінки-солдата, яка воює на рівних з чоловіками. Вона живе в однакових 3 чоловіками умовах, виконує чоловічі завдання: стріляє зі снайперської гвинтівки, з кулемета, керує військовою машиною, виносить поранених 3 поля бою під кулями тощо. На час війни вони лишили своїх дітей, свої сім’ї, власний бізнес [13].

Турботлива помічниця - це турботлива й чуйна жінка-солдат, медик, психолог, фотограф та ін. Такі жінки піклуються про бійців, допомагають їм та підтримують своєю працею і присутністю. Вони більш “жіночні”, більш схильні дотримуватися традиційного гендерного поділу праці.

Революціонерка - це категорія яка об'єднує декількох жінок, діяльність яких в АТО має революційний та інноваційний характер. Це реформаторки й інноваторки, вони ламають старі схеми й стереотипи, розвивають нові військові галузі, знаходяться на одному ієрархічному щаблі з чоловіками в армії, а їхні імена в історії загальновпізнавані.

За роки ATO (OOC) на Донбасі кількість жінок-військовослужбовців у ЗСУ зросла майже в 15 разів. В результаті бойових дій $є$ і загиблі серед них. Всього на військовій службі у Збройних силах України знаходиться понад 27000 жінок. Інформація про потреби жінок АТО/ООС в українських медіа гендерно нейтральна [13].

У статтях про жінок, які беруть участь в ООС (АТО), доволі часто згадуються потреби солдатів, проте в узагальненому вигляді. Окрім того, жодна 3 інтерв'юйованих учасниць АТО/ООС не назвала потреби саме жінок, а в їх лексиці потреби армії ототожнюються 3 потребами чоловіків: теплий одяг, зимове взуття і т.п.

Потреби жінок в АТО/ООС в таких базових речах як форма, засоби гігієни, медичне обслуговування українські медіа не згадують.

Основна проблема, з якою стикаються жінки в АТО/ООС - це повернення додому. Якщо у статтях про чоловіків, які повернулися з АТО/ООС, ПТСД проявляється в більш різкій формі: гнів, агресія, дратівливість, алкоголізм, то у жінок він проявляється більше у вигляді почуття провини, жертовності, відстороненості. 


\section{Висновки}

Підсумовуючи, можна сказати якщо стереотипи про жінок відчутно поширені у мирний час у мирних місцях, то на війні, як стверджують дослідження, розглянуті у теоретичному розділі цього звіту, маскулінність та фемінінність ще більше зміцнюються та стереотипізуються. Частіше гендерні стереотипи інтерналізовані самими жінками. Активно беручи участь в АТО, вони вважають, що їх функції, їх завдання є більш другорядними, порівняно 3 тим, що виконують чоловіки”. Спостерігається тенденція, що відмінності у ставленні до гендерних ролей в армії пов'язані, зокрема, з професією жінки на війні: солдатки частіше говорять про рівність між чоловіками і жінками на війні і добиваються поваги й ставлення до себе як до побратима. Медсестри i психологи демонструють більш традиційне ставлення до розподілу гендерних ролей і приймають турботу солдатів. Так само як належне вони сприймають те, що їм не потрібно/вони можуть не бути в такій же фізичній формі, як чоловіки. Проте це лише спостереження щодо образів жінок АТО, зображених у засобах масової інформації.
В українських медіа частіше можна зустріти оповіді про “героїв”, притому з іменами і переліком подвигів, але рідко - про “героїнь”. Жінок описують як “тендітних”, “войовничих”, “красивих”, “сміливих” “рятівниць” і “захисниць”. Спостерігається героїзація і романтизація образу жінки в АТО: участь жінки в антитерористичній операції $є$ героїчним вчинком не залежно від посади. Зустрічаються елементи зображення ролі жінки на фронті як допоміжної, підтримуючої функції для бійців. Разом 3 тим трапляються й образи жінок, які нічим не поступаються у своїх бойових вміннях та досягненнях чоловікам.

Результати дослідження показали поширення гендерно-детермінованих стереотипів, які структурують військову діяльність на чоловічу і жіночу. Але армія має потребу у ефективній, послідовній, фінансово забезпеченій гендерній політиці, яка відповідала б сучасним світовим тенденціям у гуманітарній сфері, сприяла б максимальній реалізації соціального потенціалу українських жінок та чоловіків у питанні підвищення обороноздатності держави та бойової готовності їі армії.

\section{Список літератури}

1. Голованова Т.П. Методологічні підходи та методи дослідження гендерних питань в освіті / Т.П. Голованова // Гендерна парадигма освітнього простору. - 2015. - № 1. - С. 14-16.

2. Палагнюк М.М. Гендерна проблематика: виклики сучасності / М.М. Палагнюк // Гуманітарний вісник Запорізької державної інженерної академії. - 2015. - № 60. - С. 73-83.

3. Рубан О.В. Реалії та перспективи гендерного партнерства в Україні на початку XXI століття (світоглядний аспект) / О.В. Рубан. - К.: НАН України, 2012. - 336 с.

4. Воронина О.А. Гендерное равенство как структурный элемент государственной политики в скандинавских странах / О.А. Воронина // Новый взгляд. - 2014. - № 4. - С. 133-151.

5. Гендерна політика у Збройних Силах України: проблеми теорії та практики: монографія / В.П. Кротиков, В.М. Малюга, В.Л. Топальський та ін.; за заг. ред. О.М. Олійника. - К.: НДЦ ГП ЗСУ, 2012. - 334 с.

6. Клименко Н.Г. Роль і місце жінки - військовослужбовця в Україні / Н.Г. Кліменко // Економіка та держава. 2014. - C. 116-119.

7. Дяченко О. Озброєні і дуже чарівні / О. Дяченко // Військо України. - 2011. - № 3(129). - С. 28-29.

8. Калагін Ю.А. Гендерний аспект типологізаціі особистості військовослужбовців Збройних Сил України / Ю.А. Калагін // Український соціум. - 2013. - № 3(46). - С. 104-107.

9. Єрмолаєва Т.В. Гендерні стереотипи у сучасному українському суспільстві / Т.В. Єрмолаєва, К.В. Шваб // Вісник університету імені Альфреда Нобеля. - 2017. - № 1(13). - С. 92-96.

10. Дубчак Н.І. Жінки у Збройних силах України: проблеми гендерної політики / Н.І. Дубчак // Стратегічні пріоритети. - 2008. - № 4(9). - С. 187-191.

11. Правдивець Н.О. Психологічні чинники та етапи розвитку професійної ідентичності у жіноквійськовослужбовців / Н.О. Правдивець // Вісник Національної академії Державної прикордонної служби України. 2013. - № 2. - Режим доступу: http://nbuv.gov.ua/UJRN/Vnadps_2013_2_26.

12. Мороз Т. Кількість жінок у нашому війську за десять років збільшилась у 15 разів [Електронний ресурс] / Т. Мороз. - Режим доступу: https://armyinform.com.ua/2019/09/kilkist-zhinok-u-nashomu-vijsku-za-desyat-rokiv-zbilshylas-u15-raziv.

13. Марценюк Т. “Невидимий батальйон”: участь жінок у військових діях в АТО (соціологічне дослідження) / за заг. ред. Тамари Марценюк. - К.: ФОП Клименко, 2016. - 80 с.

\section{References}

1. Golovanova, T.P. (2015), “Metodologichni pidhodi ta metodi doslidzhennya gendernih pitan v osviti” [Methodological approaches and methods of research of gender issues in education], Gender paradigm of educational space, No. 1, pp. 14-16.

2. Palagnyuk, M.M. (2015), “Genderna problematika: vikliki suchasnosti” [Gender issues: challenges of today], Humanitarian Bulletin of the Zaporizhia State Engineering Academy, No. 60, pp. 73-83. 
3. Ruban, O.V. (2012), “Realiyi ta perspektivi gendernogo partnerstva v Ukrayini na pochatku XXI stolittya (svitoglyadnij aspekt)" [Realities and prospects of gender partnership in Ukraine at the beginning of the XXI century (worldview aspect)], NAN Ukrayini, Kyiv, 336 p.

4. Voronina, O.A. (2014), "Gendernoe ravenstvo kak strukturnyj element gosudarstvennoj politiki v skandinavskih stranah" [Gender equality as a structural element of public policy in the Scandinavian countries], A new Look, No. 4, pp. 133-151.

5. Krotikov, V.P., Malyuga, V.M. and Topalskij, V.L. (2012), “Genderna politika u Zbrojnih Silah Ukrayini: problemi teoriyi ta praktiki” [Gender policy in the Armed Forces of Ukraine: problems of theory and practice], NDC GP ZSU, Kyiv, 334 p.

6. Klimenko, N.G. (2014), "Rol i misce zhinki - vijskovosluzhbovcya v Ukrayini” [The role and place of a woman - a serviceman in Ukraine], Economy and State, pp. 116-119.

7. Dyachenko, O. (2011), “Ozbroyeni i duzhe charivni” [Armed and very charming], The Army of Ukraine, No. 3(129), pp. 28-29.

8. Kalagin, Yu.A. (2013), “Gendernij aspekt tipologizacii osobistosti vijskovosluzhbovciv Zbrojnih Sil Ukrayini” [Gender aspect of typology of personality of servicemen of the Armed Forces of Ukraine], Ukrainian Society, No. 3(46), pp. 104-107.

9. Yermolayeva, T.V. and Shvab, K.V. (2017), “Genderni stereotipi u suchasnomu ukrayinskomu suspilstvi” [Gender stereotypes in modern Ukrainian society], Bulletin of Alfred Nobel University, No. 1(13), pp. 92-96.

10. Dubchak, N.I. (2008), “Zhinki u Zbrojnih silah Ukrayini: problemi gendernoyi politiki” [Women in the Armed Forces of Ukraine: Problems of Gender Policy], Strategic Priorities, No. 4(9), pp. 187-191.

11. Pravdivec, N.O. (2013), "Psihologichni chinniki ta etapi rozvitku profesijnoyi identichnosti u zhinokvijskovosluzhbovciv" [Psychological factors and stages of development of professional identity in women servicemen], Bulletin of the National Academy of the State Border Guard Service of Ukraine, No. 2, available at: www.nbuv.gov.ua/UJRN/Vnadps_2013_2_26.

12. Moroz, T. (2019), "Kilkist zhinok u nashomu vijsku za desyat rokiv zbilshilas u 15 raziv" [The number of women in our army has increased 15 times in ten years], available at: www.armyinform.com.ua/2019/09/kilkist-zhinok-u-nashomu-vijsku-zadesyat-rokiv-zbilshylas-u-15-raziv.

13. Marcenyuk, T. (2016), “Nevidimij bataljon”: uchast zhinok u vijskovih diyah v ATO (sociologichne doslidzhennya)" ["Invisible Battalion": women's participation in hostilities in the anti-terrorist operation (sociological study)], FOP Klimenko, Kyiv, $80 \mathrm{p}$.

Надійшла до редколегії 28.02.2020

Схвалена до друку 10.03.2020

\section{Відомості про авторів:}

\section{Петрова Людмила Олексадрівна}

кандидат філософських наук

доцент

учений секретар Харківського національного

університету Повітряних Сил ім. І. Кожедуба,

Харків, Україна

https://orcid.org/0000-0002-9341-1030

\section{Панфілов Олександр Юрійович}

доктор філософських наук

професор

професор кафедри

Харківського національного університету

Повітряних Сил ім. І. Кожедуба,

Харків, Україна

https://orcid.org/0000-0002-8997-0120

\section{Information about the authors:}

\author{
Liudmyla Petrova \\ Candidate of Philosophical Sciences \\ Associate Professor \\ of Ivan Kozhedub Kharkiv \\ National Air Force University, \\ Kharkiv, Ukraine \\ https://orcid.org/0000-0002-9341-1030
}

Oleksandr Panfilov
Doctor of Philosophy
Professor
Professor of Department
of Ivan Kozhedub Kharkiv
National Air Force University,
Kharkiv, Ukraine
https://orcid.org/0000-0002-8997-0120

\section{ГЕНДЕРНОЕ РАВЕНСТВО В АРМИИ: УЧАСТИЕ ЖЕНЩИН В ВОЕННЫХ ДЕЙСТВИЯХ В АНТИТЕРОРИСТИЧЕСКОЙ ОПЕРАЦИИ (ОПЕРАЦИИ ОБЬЕДИНЕННЫХ СИЛ)}

Л.А. Петрова, А.Ю. Панфилов

Статья посвящена анализу актуальных проблем гендерной политики в армии. Обоснованно принци равенства, который имеет несколько проявлений, одним из которых является приничи гендерного равенства, что означает равный подход ко всему независимо от пола. Женщины занимают в основном так называемые феминизированные должснсти: медсестринские, связанные с финансовой деятельностью, материально-техническим и коммуникационным обеспечением. Женщины в армии сталкиваются с дискриминачией по признаку пола, с предрассудками. Проанализированы гендерные стереотипы, гендерные нормативы поведения и проблемы гендерной идентификации в современном украинском обществе. Доказано, что на сегодня гендерная политика в Вооруженных Силах Украины не полностью отражает 
общемировые тенденции в сфере гендерных отномений. На основании данных интервьюирования рассматривается роль женщин в АТО / ООС на востоке Украины, их борьба за равные права и возможности в своем государстве.

Ключевые слова: армия, гендер, гендерний стереотип, военнослужащие-женщины, гендерное равенство.

\title{
GENDER EQUALITY IN THE ARMY: WOMEN'S PARTICIPATION IN MILITARY ACTION IN ANTI-TERRORIST OPERATION (JOINT FORCES OPERATION)
}

\author{
L. Petrova, O. Panfilov
}

The immediacy of the problem of gender politics in the army is caused by the following: general tendency of uptick in problems of gender politics in modern day society; increasing number of female soldiers and female workers in the Armed Forces of Ukraine; increasing number of military occupational specialties and positions which female soldiers are appointed on; dominance of obsolete stereotypes on place and role of women in the army; need for determination of essence and content of gender politics in the Armed Forces of Ukraine, priority directions of its implementation. The principle of equality has several manifestations, one of which is the principle of gender equality, which means an equal approach to everything regardless of gender. The article considers gender stereotypes, gender norms of behavior and problems of gender identification in modern Ukrainian society. The problems of gender differences in personality traits are due to the fact that due to the constant dynamic changes in the world, there are more and more questions about the impact of certain gender stereotypes on the professional activities of the individual. The relevance of the topic of research is due to modern civilizational priorities. According to them, equality of rights and opportunities of men and women is considered the key to peace, prosperity and sustainable social development. Meanwhile, Ukrainians often with great resistance perceive gender strategies initiated by various international organizations, considering them the main threat to the existence of the social order that determined their ethnocultural identity. It was established that gender conflicts are a natural consequence of the pressure of gender stereotypes, which significantly limit the possibilities of social realization of an individual through an externally given requirement to correct their behavior over given social standards during periods of radical transformations in the gender system of society. There are author highlights few topical issues in implementation of gender politics in the army in present-day conditions. The first problem is a problem of equality of men and women while on active service: limitations of positions which female soldiers can be appointed on; limitation of a woman's right for military education majoring in certain specialties; differences in age restrictions when concluding a military service contract and age limits to be on military service; differences in military service between men and women depending on the number of children. The second problem is a problem of violating a principle of gender equity of male and female soldiers with respect to kinds of responsibility and a way of enduring the punishment for violating a certain military career structure/ The third problem is a problem of violating a principle of gender equity of male and female soldiers with respect to performance of military duties: daily duty (female soldiers are not appointed for daily duties or they can be appointed to certain types of daily duty) and business trips (female soldiers who have children under 14 years old can be assigned to a business trip only upon their consent).

Keywords: army, gender, gender stereotype, female military personnel, gender equality. 